\title{
Design and Analysis of the Flat Honeycomb Sandwich Structures
}

\author{
Zoran Petrović ${ }^{1)}$ \\ Ivan Lazarević ${ }^{1)}$
}

\begin{abstract}
Structural sandwich is a unique form of the composite structure, and it finds a widespread use in the aerospace industry, where weight saving is a primary concern. The major difference between analysis procedures for sandwich construction and those for homogeneous structural elements is the inclusion of core shear effects on deflection, buckling and stress. The design procedure given in this article is intended to guide the designer in sizing the sandwich parts for primary loading properly. These procedures are usually iterative, and optimum design may require the design of several face-core combinations. Comparing the results obtained through the analytical procedure and Finite Element Analysis (FEA) one can conclude their good agreement. Differences for most of the results are from $10 \%$ to $15 \%$, which is quite satisfactory, taking into account that the analytical models are formed on the basis of a number of assumptions and approximations.
\end{abstract}

Key words: sandwich structure, honeycomb core, application in aviation, aircraft, aircraft structure, face, structural analysis, finite element analysis.

\section{Notation and symbols}

$M x$

$D$

$V x$

$N$

$a$

$b$

$c$

$K_{1 a}$

$K_{2 b}$

$K_{2 a}$

$K_{3}$

- Flexural stiffness

- Shear at the section

- Shear stiffness

- Thickness of the core

- Thicknesses of faces 1 and 2 direction ribbon direction

- Thickness correction factor

- Thickness correction factor

- Dimensionless shear parameter panel, or $G_{Y Z} / G_{X Z}$

- Core shear coefficient for side- $b$

- Core shear coefficient for side-a

- Panel deflection coefficient
- Bending moment at a given section

- Length of the longer side of a pressure loaded panel

- Length of the shorter side of a pressure loaded panel

- Distance between the centroids of the faces

- Total thickness of the sandwich element

- Longitudinal direction, parallel to the core ribbon

- Short transverse direction, trough the core thickness

- Transverse direction, perpendicular to the core

- Allowable core shear stress in the LT plane

- Allowable core shear stress in the WT plane

- Core shear modulus in the LT plane

- Core shear modulus in the WT plane

- Core shear modulus in the XZ plane

- Core shear modulus in the YZ plane

- Allowable core shear stress in the LT plane

- Allowable core shear stress in the WT plane

- Elastic modulus of the facing material

- Poisson's ratio for the facing material

- Mean radius of curvature at the neutral axis of the

- Face stress coefficient for the " $b$ " direction

-Face stress coefficient for the " $a$ " direction $f_{1,2} \quad$ - Maximum face stresses

$f_{s b} \quad$ - Core shear stress at the midlength of side- $\mathrm{b}$

$f_{s a} \quad$-Core shear stress at the midlength of side-a

$M \mathrm{~S}_{1,2} \quad$ - Margin of safety for each facesheet

$M S_{s b, s a}$ - Margins of safety for core shear

\section{Introduction}

A sandwich panel consists of three discrete structural elements: two relatively thin facings, bonded to a thicker, lightweight core (Fig.1).

Depending on the condition that a plane or a missile is exposed to, the face material may be aluminum alloys, reinforced plastic, titanium alloys, heat resistant steel, etc. Materials and geometric forms of the core can be very diverse. A very popular type of the core is a "honeycomb core", which consists of a thin film formed in the hexagonal cell perpendicular to the faces [1].

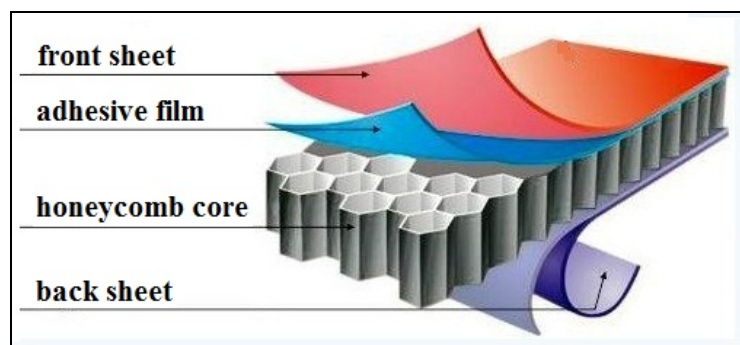

Figure 1. Elements of the honeycomb sandwich structures

Structural sandwich is a unique form of the composite structure, and it finds a widespread use in the aerospace industry, where weight saving is a primary concern. Most commercial airliners and helicopters (Figure 2), and almost all military air and space aircraft widely used the sandwich construction [3].

From the structural point of view, the main role of the core is separating and keeping external faces at a given distance in

\footnotetext{
1) $204^{\text {th }}$ Air Force Brigade RS, Pukovnika Milenka Pavlovića bb, 11273 Batajnica, SERBIA

Correspondence to: Zoran Petrović; e-mail: pzoran.pele@gmail.com
} 
order to provide stability against buckling. Essentially, the existence and the thickness of the core create and maintain the required moment of inertia of the cross section.

The major difference between the analysis procedures for sandwich construction and those for homogeneous structural elements is the inclusion of core shear effects on deflection, buckling and stress [4]. The reasons for the inclusion of this effect are discussed below.

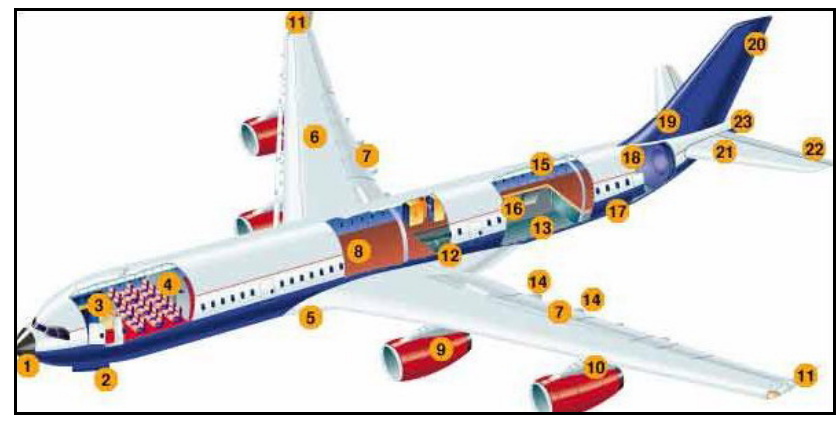

Figure 2. The application of structural sandwich in construction of civil aircraft: 1 . Radome 2. Landing Gear Doors and Leg Fairings 3. Galley, Wardrobes, Toilets 4. Partitions 5. Wing to Body Fairing 6. Wing Assembly 7. Flying Control Surfaces 8. Passenger Flooring 9. Engine Nacelles and Thrust Reversers 10. Pylon Fairings 11. Winglets 12. Keel Beam 13. Cargo Flooring 14. Flaptrack Fairings 15. Overhead Storage Bins 16. Ceiling and Side Wall Panels 17. Airstairs 18. Pressure Bulkhead 20. Rudder 21. Horizontal Stabilizer 22. Elevator 23. Tail Cone [3]

The analysis procedures outlined in this paper are intended for use in the structural analysis of both preliminary and final designs of sandwich parts. In fact, the analytical procedure of analysis with an example, which follows, is primarily intended to guide the designer in sizing the sandwich parts for primary loading properly. These procedures are usually iterative, and optimum design may require the design of several face-core combinations [5].

\section{Analysis of the flat honeycomb sandwich panels with isotropic faces}

This chapter presents data and methods for the design and analysis of simply supported flat sandwich panels under uniform pressure loads.

\section{Sandwich Stiffness}

The stiffness of a structure is defined as its ability to resist deformation when subjected to an applied load. The deformations of the sandwich structures, unlike those of monolithic beams, are significantly affected by the contributions of shear deformation.

The deflection of a monolithic beam or plate, according to the elementary beam theory, is governed by the solution of the following differential equations [4]:

$$
\frac{d^{2} y}{d x^{2}}=\frac{M_{x}}{D}+\frac{1}{N}\left(\frac{d V_{x}}{d x}\right)
$$

$M x$ - the bending moment at a given section

$D$ - flexural stiffness

$V x$ - shear at the section

$N$ - shear stiffness

For most monolithic beams having constant cross sections and large (compared to the beam depth) spans, the second term, which accounts for the shear deformation, may be neglected. This simplifying assumption may normally be made because the shear stiffness, $N$, is relatively large. However, since sandwich materials have relatively low core shear module, the shear stiffness of most sandwich elements is not so large and this assumption does not hold. Therefore, the deflection calculations for sandwich elements must include the shear contribution [4].

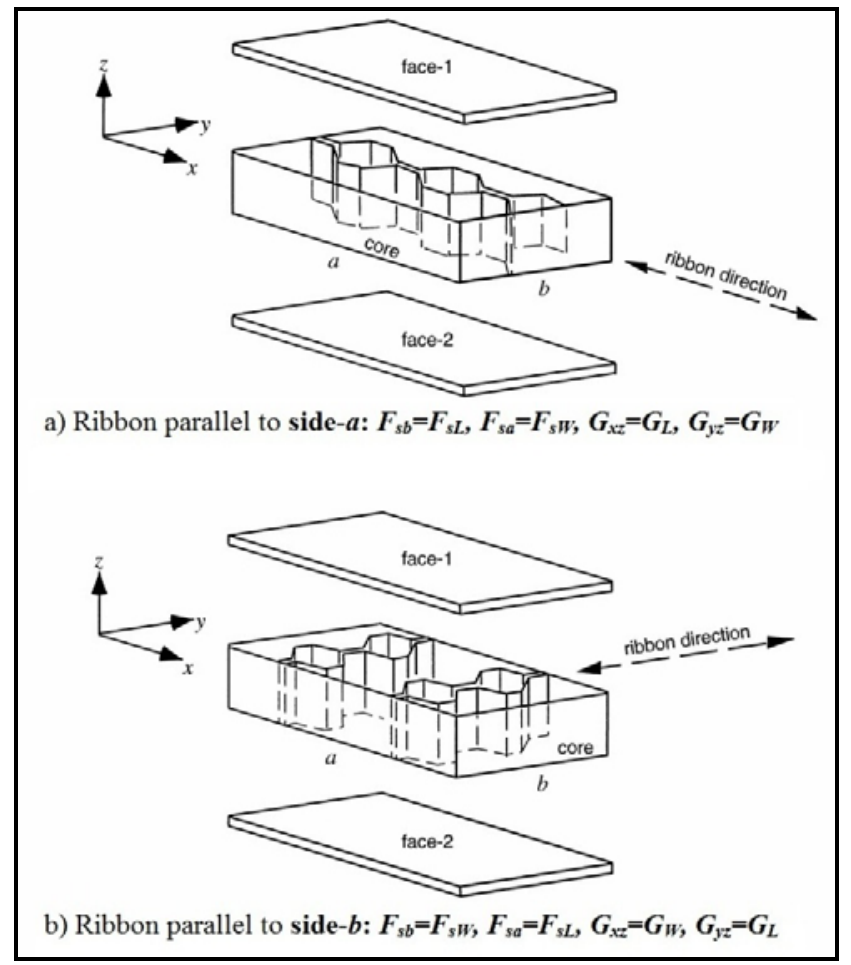

Figure 3. Core orientation to determine $F_{\mathrm{sa}}, \mathrm{F}_{\mathrm{sb}}, \mathrm{G}_{\mathrm{XZ}}$ and $\mathrm{G}_{\mathrm{YZ}}$ [4]

Shear module and strength allowable are based on the core ribbon direction, which may be oriented either parallel to side-a or side-b. Typical values should be used for the core shear module $\left(G_{X Z}, G_{Y Z}\right)$, while statistically derived allowable should be used for the core shear strengths $\left(F_{S L}, F_{S W}\right)$. Both the shear modulus and shear strength must be corrected for core thickness and temperature. Core material properties, along with the appropriate correction curves can be found in the relevant literature (for example BDM-4231 through BDM-4240 [6]). Figures 3 and 4 more clearly define the terms associated with the core ribbon.

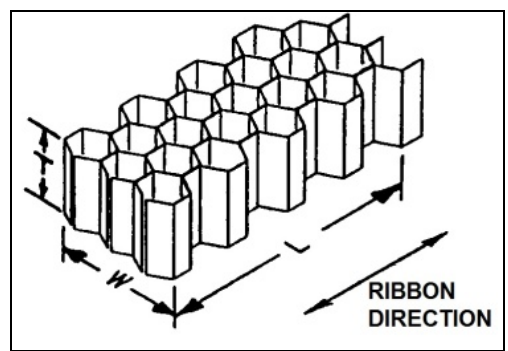

Figure 4. Definition of the core ribbon terms

\section{Analysis Procedure}

The analysis procedure for the flat honeycomb sandwich panels with similar isotropic faces subjected to uniform pressure is outlined below and is followed by an example analysis [5].

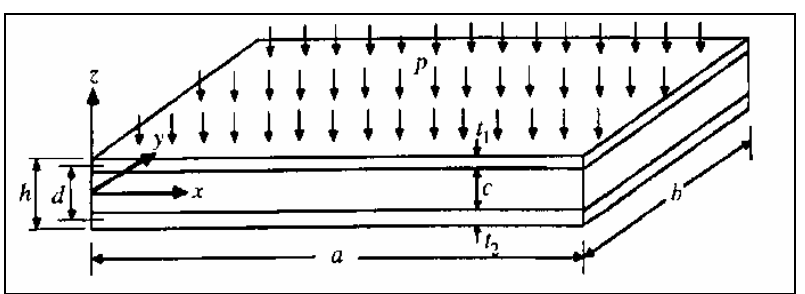

Figure 5. Geometry and loading conventions [5] 
Using the data provided in Table 1, determine whether the given panel will withstand the design load. The configuration is shown in Fig.5.

Table 1. Example data for a uniform pressure loaded flat panel

\begin{tabular}{|c|c|c|c|c|c|c|c|}
\hline \multicolumn{2}{|c|}{$\begin{array}{c}\text { Environmental } \\
\text { Temperature }\end{array}$} & \multicolumn{6}{|c|}{$\begin{array}{c}70^{\circ} \mathrm{F} \\
\left(21^{\circ} \mathrm{C}\right)\end{array}$} \\
\hline \multicolumn{2}{|c|}{ Face Material } & \multicolumn{6}{|c|}{ Ti-6Al-4V (Annealed) } \\
\hline \multicolumn{2}{|c|}{ Core Material } & \multicolumn{6}{|c|}{ Aluminum Alloy Honeycomb 6.5-3/8-50, (5052) } \\
\hline \multicolumn{2}{|c|}{ Core Orientation } & \multicolumn{6}{|c|}{ Longitudinal direction parallel to $x$-axis $G_{x z}=G_{L}$} \\
\hline \multirow{4}{*}{$\begin{array}{c}\text { Example } \\
\text { Values }\end{array}$} & \multirow{2}{*}{ (AS) } & $p$ (psi) & $c$ (in) & $t_{1}$ (in) & $t_{2}$ (in) & $a$ (in) & $b$ (in) \\
\hline & & 65 & 1,25 & 0,015 & 0,015 & 20 & 16 \\
\hline & \multirow{2}{*}{ (SI) } & $p\left(\mathrm{~N} / \mathrm{mm}^{2}\right)$ & $c(\mathrm{~mm})$ & $t_{1}(\mathrm{~mm})$ & $t_{2}(\mathrm{~mm})$ & $a(\mathrm{~mm})$ & $b(\mathrm{~mm})$ \\
\hline & & 0,44816 & 31,75 & 0,381 & 0,381 & 508 & 406 \\
\hline
\end{tabular}

Step 1: Determine the panel aspect ratio $b / a$.

$$
\frac{b}{a}=\frac{16}{20}=0,8
$$

Step 2: Identify $G_{X Z}$ as $G_{L}$ or $G_{W}$ using Fig.3 and obtain core properties, for example by using data from BDM-4231 through BDM-4240. Use typical values for the core shear modulus corrected for the applicable thickness and temperature [6].

$$
\begin{aligned}
& F_{s a}=F_{s W}=\left(K_{\text {thkW }}\right) \cdot F_{\text {sWnom }}= \\
& =0,87 \cdot 306=266,33 \mathrm{psi}\left(1,83 \mathrm{~N} / \mathrm{mm}^{2}\right) \\
& F_{s b}=F_{s L}=\left(K_{\text {thkL }}\right) \cdot F_{\text {sLnom }}= \\
& 0,83 \cdot 500=415 \mathrm{psi}\left(2,861 \mathrm{~N} / \mathrm{mm}^{2}\right) \\
& G_{y z}=G_{W}=49700 \mathrm{psi}\left(342,67 \mathrm{~N} / \mathrm{mm}^{2}\right) \\
& G_{x z}=G_{L}=103900 \mathrm{psi}\left(716,36 \mathrm{~N} / \mathrm{mm}^{2}\right)
\end{aligned}
$$

Step 3: Determine the facesheet material properties $E, \mu$, $F_{c y}$ and $F_{t u}$, corrected for temperature (from BDM-4143 [7]). Determine the core thickness, $c$, and calculate $V$.

$$
\begin{gathered}
c=h-\left(t_{1}+t_{2}\right) \\
V=\left[\frac{\pi^{2} c E}{\left(1-\mu^{2}\right) b^{2} G_{x z}}\right]\left(\frac{t_{1} t_{2}}{t_{1}+t_{2}}\right)
\end{gathered}
$$

$E=16000000$ psi $\left(110.316 \mathrm{~N} / \mathrm{mm}^{2}\right), \mu=0,31$,

$$
\begin{gathered}
F_{t u}=134000 \mathrm{psi}\left(923.89 \mathrm{~N} / \mathrm{mm}^{2}\right) \\
F_{c y}=133000 \mathrm{psi}\left(917 \mathrm{~N} / \mathrm{mm}^{2}\right) \\
c=1,25 \text { in }(31,75 \mathrm{~mm}) \\
V=0,0615
\end{gathered}
$$

Step 4: Determine $R$. Using $R$ and $V$, determine $K_{l b}$ and $K_{l a}$ from Figures 6 and 7 .

If

If

$$
G_{x z}=G_{L} \text { and } G_{L}>G_{W} ; R=0,4
$$

If

$$
G_{x z}=G_{W} \text { and } G_{L}>G_{W} ; R=2,5
$$

$$
\begin{gathered}
G_{x z}=G_{L} ; R=1,0 \\
K_{1}=\max \left(K_{1 b}, K_{1 a}\right) \\
R=0,4 \Rightarrow K_{1 b}=0,0642 ; K_{1 a}=0,0518 \\
K_{1 b}>K_{1 a} \Rightarrow K_{1}=K_{1 b}=0,0642
\end{gathered}
$$

Step 5: Calculate the distance between facing centroids $d$ and determine the maximum face stresses.

$$
\begin{gathered}
d=h-\frac{t_{1}+t_{2}}{2}=1,265 \text { in }(32,13 \mathrm{~mm}) \\
f_{1,2}=K_{1} \cdot \frac{p \cdot b^{2}}{d \cdot t_{1,2}} \\
t_{1}=t_{2} \Rightarrow f_{1}=f_{2}=56300 \mathrm{psi}\left(388,17 \mathrm{~N} / \mathrm{mm}^{2}\right)
\end{gathered}
$$

(Note that since $p$ is positive, $f_{1}$ is compressive and $f_{2}$ is tensile. $F_{c y}$ is used to calculate the MS for face- 1 and $F_{t u}$ is used for face-2).

Step 6: Determine the margin of safety for each facesheet.

$$
M S_{1,2}=\frac{F_{\text {allow }}}{f_{1,2}}-1
$$

$$
\begin{gathered}
F_{\text {allow }}=F_{t u}, \text { for facesheet in tension } \\
F_{\text {allow }}=F_{c y}, \text { for facesheet in compression }
\end{gathered}
$$

$$
\begin{aligned}
& M S_{1}=1,362 \\
& M S_{2}=1,380
\end{aligned}
$$

Step 7: Determine the coefficients $K_{2 b}$ and $K_{2 a}$ from Fig.8 and calculate the maximum core shear stresses $f_{s b}$ and $f_{s a}$.

From figure $8 \Rightarrow K_{2 b}=0,3519 ; K_{2 a}=0,3819$

$$
\begin{gathered}
f_{s b}=K_{2 b} \cdot p \cdot\left(\frac{b}{d}\right) \\
f_{s a}=K_{2 a} \cdot p \cdot\left(\frac{b}{d}\right) \\
f_{s b}=289,3 \text { psi }\left(1,994 . \mathrm{N} / \mathrm{mm}^{2}\right) \\
f_{s a}=314,0 \text { psi }\left(2.164 \mathrm{~N} / \mathrm{mm}^{2}\right)
\end{gathered}
$$

Step 8: Determine the margins of safety for the core shear; the orientation of the core will determine how $F_{s a}$ and $F_{s b}$ correspond to the core shear allowable $F_{S L}$ and $F_{S W}$, see Fig.3.

$$
\begin{gathered}
M \cdot S_{\cdot s b}=\frac{F_{s b}}{f_{s b}}-1 \\
M S_{s_{s a}}=\frac{F_{s a}}{f_{s a}}-1 \\
M S_{s b}=0,434 \\
M S_{s a}=-0,152
\end{gathered}
$$

Step 9: Determine the deflection coefficient $K_{3}$ from Fig.9 and check the maximum deflection of the panel $\delta$ (at the center of the panel).

$$
\begin{gathered}
\delta=-\left[\frac{K_{3} \cdot p \cdot b^{4} \cdot\left(1-\mu^{2}\right)}{E \cdot d^{2}}\right] \cdot\left(\frac{t_{1}+t_{2}}{t_{1} \cdot t_{2}}\right) \\
\delta=-0,1384 \text { in }(3,5 \mathrm{~mm})
\end{gathered}
$$


Step 10: Check the compressive face for local instability failure by consulting the appropriate BDM-6716 (Intracell buckling of the honeycomb sandwich structures), BDM-6718 (Face wrinkling of the flat honeycomb sandwich panels with isotropic faces) and BDM-6720 (Shear crimping of the honeycomb sandwich structures).

The obtained maximum stresses in the faces and the maximum core shear stresses on the side $b$ are below the allowable limit stresses. However, the maximum shear stress on the side $a$ is above the limit stress, due to which designed honeycomb sandwich beams do not provide the required level of security. In order to ensure the appropriate level of security the plates will increase the thickness of faces.

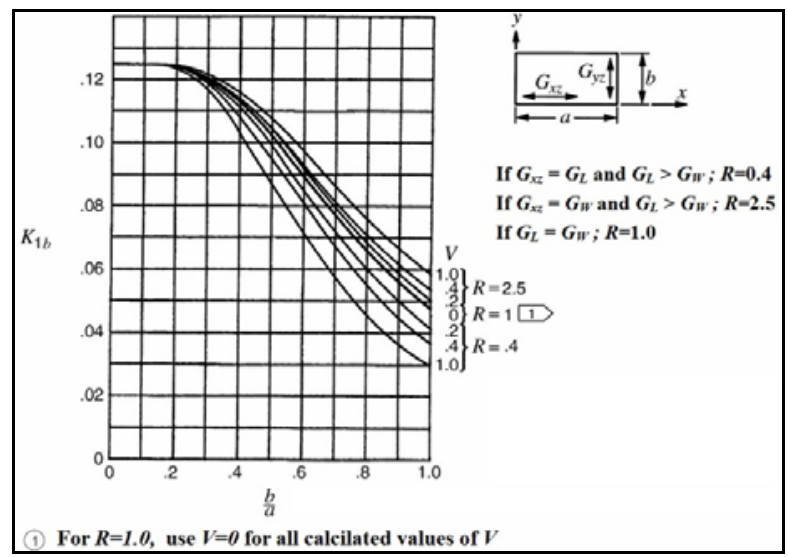

Figure 6. Face stress coefficient $\mathrm{K}_{1 \mathrm{~b}}$ for the " $\mathrm{b}$ " direction [5]

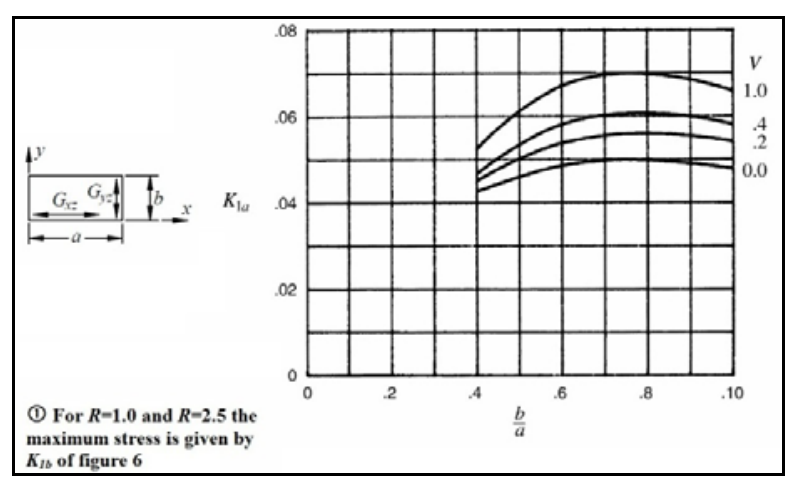

Figure 7. Face stress coefficient $\mathrm{K}_{1 \mathrm{a}}$ for the "a" direction $(\mathrm{R}=0.4)$ [5]

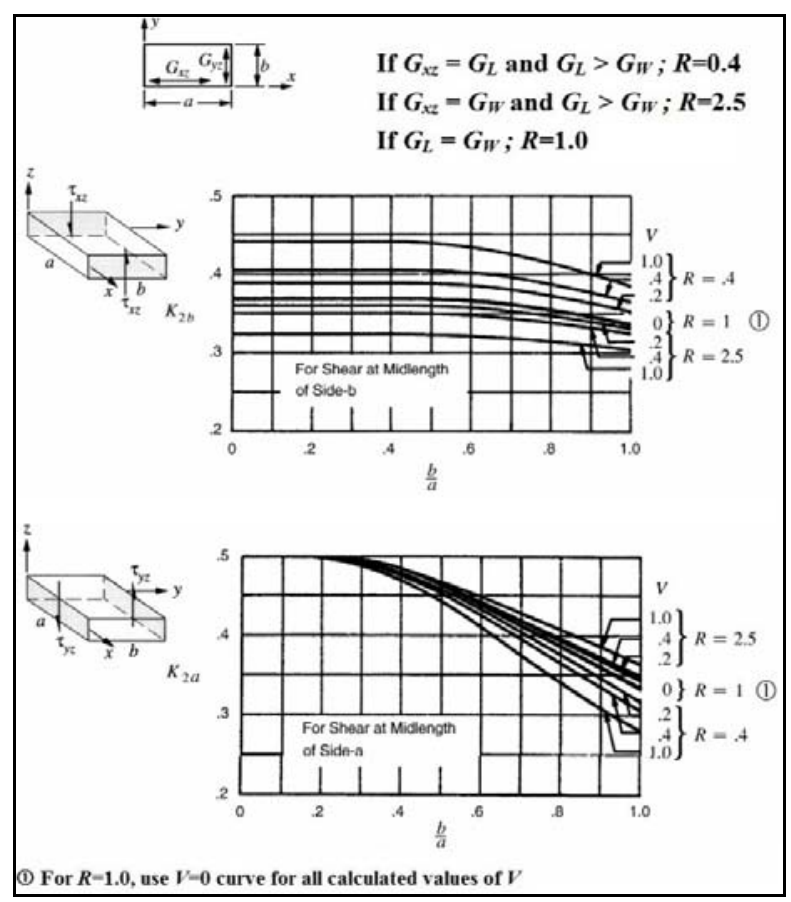

Figure 8. Core shear stress coefficient $K_{2}[5]$

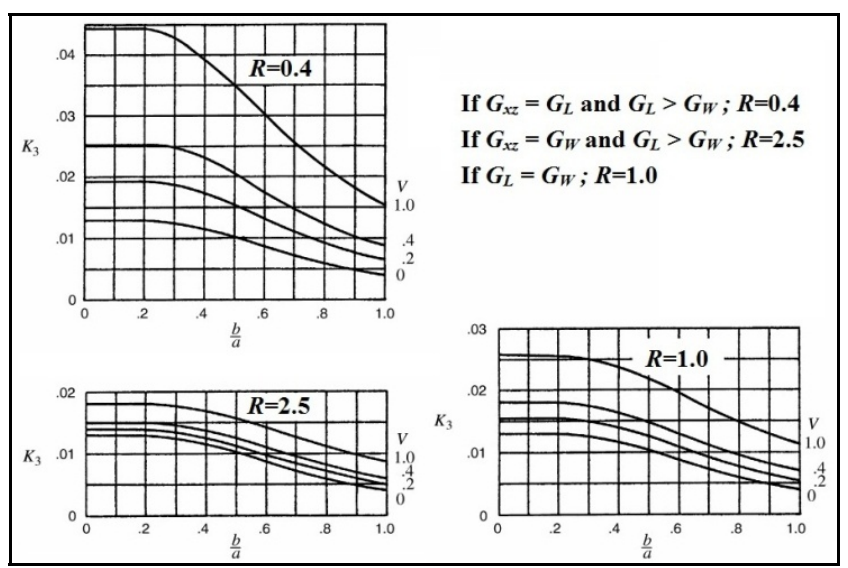

Figure 9. Panel deflection coefficient $K_{3}[6]$

BOEING DESIGN MANUAL

BDM-4233

3 STATIC MECHANICAL PROPERTIES (Continued)

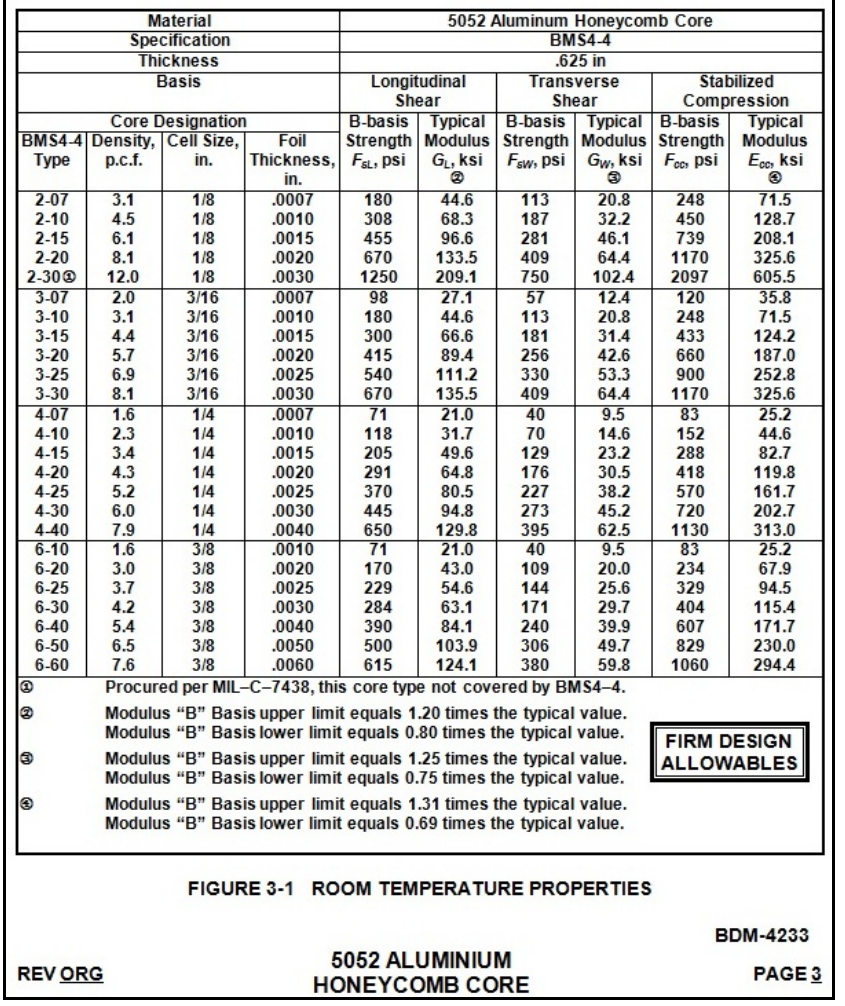

Figure 10. Static mechanical properties of the aluminum honeycomb core5052 aluminum [6]

As already mentioned, these procedures are usually iterative and optimum design may require the design of several face-core combinations.

It is evident that increasing the thickness of faces resulting in increased margins of safety for faces and core. However, increasing the thickness of faces does not significantly affect the increase in the margins of safety for core shear. Therefore, we will increase the thickness of the core.

By increasing the thickness of the faces and thickness of the core we get an acceptable combination of face-core (thickness of the faces $t_{1,2}=0,035 \mathrm{in}$ and thickness of the core $c=1,50 \mathrm{in}$ ) which can support the design load. The maximum deflection of the panel $\delta$ is $-0,0502$ in $(-1,28 \mathrm{~mm})$. 


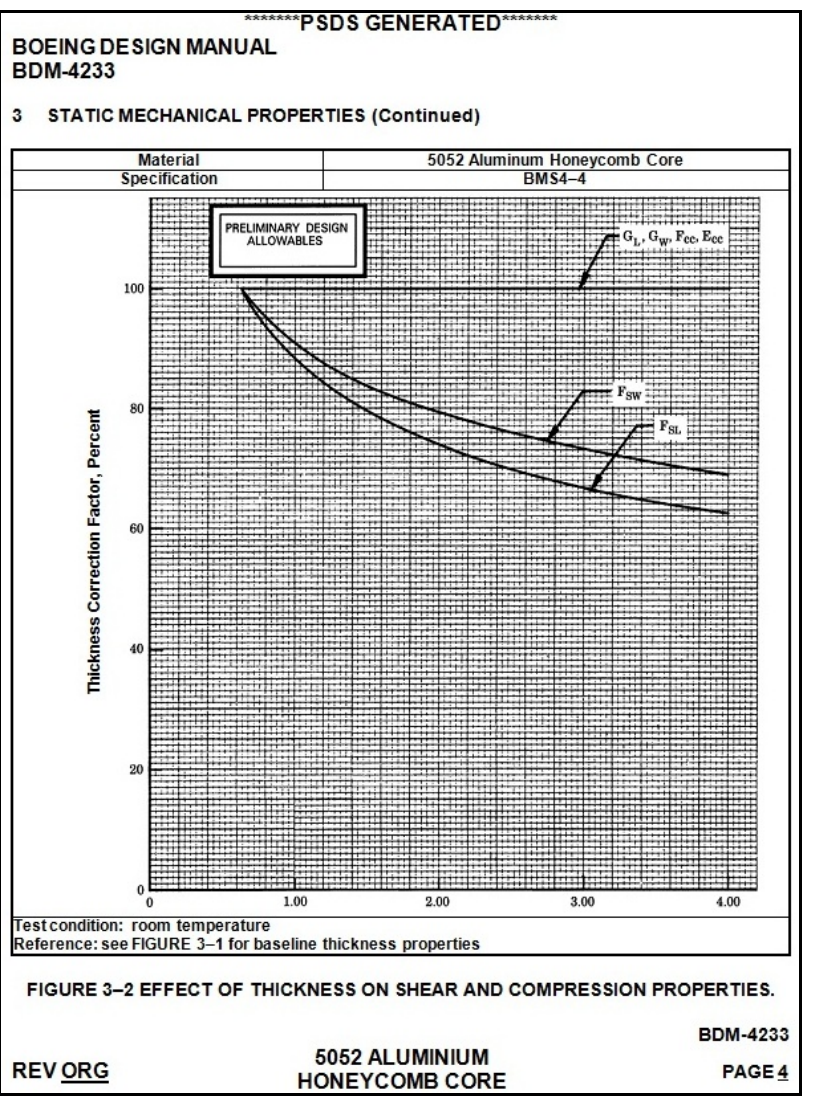

Figure 11. Effect of thethickness on shear and compression properties -5052 aluminum [6]

Table 2. Comparative analysis of the honeycomb sandwich panels

\begin{tabular}{|c|c|c|c|c|c|c|}
\hline$c$ [in] & \multicolumn{3}{|c|}{1,25} & \multicolumn{3}{|c|}{1,50} \\
\hline$t_{1,2}$ [in] & 0,015 & 0,025 & 0,035 & 0,015 & 0,025 & 0,035 \\
\hline$b / a$ & 0,8 & 0,8 & 0,8 & 0,8 & 0,8 & 0,8 \\
\hline$F_{s a}=F_{s W}[p s i]$ & 266,22 & 266,22 & 266,22 & 257,04 & 257,04 & 257,04 \\
\hline$F_{s b}=F_{s L}[p s i]$ & 415 & 415 & 415 & 400 & 400 & 400 \\
\hline$G_{X Y}=G_{W}[p s i]$ & 49700 & 49700 & 49700 & 49700 & 49700 & 49700 \\
\hline $\mathrm{G}_{\mathrm{XZ}}=\mathrm{G}_{\mathrm{L}}[\mathrm{psi}]$ & 103900 & 103900 & 103900 & 103900 & 103900 & 103900 \\
\hline$V$ & 0,0615 & 0,1025 & 0,1435 & 0,0738 & 0,1230 & 0,1722 \\
\hline$R$ & 0,4 & 0,4 & 0,4 & 0,4 & 0,4 & 0,4 \\
\hline$K_{1 b}$ (chart) & 0,0642 & 0,0629 & 0,0617 & 0,0638 & 0,0623 & 0,0608 \\
\hline$K_{1 a}$ (chart) & 0,0518 & 0,0531 & 0,0543 & 0,0522 & 0,0537 & 0,0552 \\
\hline$K_{1}=\max \left(K_{1 b}, K_{1 a}\right)$ & 0,0642 & 0,0629 & 0,0617 & 0,0638 & 0,0623 & 0,0608 \\
\hline$h$ [in] & 1,280 & 1,300 & 1,320 & 1,530 & 1,550 & 1,570 \\
\hline$d$ [in] & 1,265 & 1,275 & 1,285 & 1,515 & 1,525 & 1,535 \\
\hline$f_{1,2}[\mathrm{psi}]$ & 56300 & 32836 & 22828 & 46716 & 27191 & 18831 \\
\hline$M S_{1}$ & 1,362 & 3,050 & 4,826 & 1,847 & 3,891 & 6,063 \\
\hline$M S_{2}$ & 1,380 & 3,081 & 4,870 & 1,868 & 3,928 & 6,116 \\
\hline$K_{2 b}$ (chart) & 0,3519 & 0,3499 & 0,3479 & 0,3513 & 0,3488 & 0,3464 \\
\hline$K_{2 a}$ (chart) & 0,3819 & 0,3799 & 0,3778 & 0,3813 & \begin{tabular}{|l|}
0,3788 \\
\end{tabular} & 0,3764 \\
\hline$f_{s b}[\mathrm{psi}]$ & 289,3 & 285,4 & 281,6 & 241,2 & 237,9 & 234,7 \\
\hline$f_{s a}[\mathrm{psi}]$ & 314,0 & 309,9 & 305,8 & 261,8 & 258,3 & 255,0 \\
\hline$M S_{\mathrm{sb}}$ & 0,434 & 0,454 & 0,474 & 0,659 & 0,682 & 0,704 \\
\hline$M S_{\mathrm{sa}}$ & $-0,152$ & $-0,141$ & $-0,129$ & $-0,018$ & $-0,005$ & 0,008 \\
\hline$K_{3}$ & 0,0069 & 0,0075 & 0,0082 & 0,0071 & \begin{tabular}{|l|}
0,0078 \\
\end{tabular} & 0,0086 \\
\hline$\delta[$ in $]$ & $-0,1384$ & $-0,0888$ & $-0,0683$ & $-0,0993$ & $-0,0646$ & $-0,0502$ \\
\hline
\end{tabular}

\section{Analysis of the flat honeycomb sandwich plates by the Finite Element Method}

The modern design processes of the new, as well as monitoring the integrity of the existing structures in the real exploitation conditions, is unthinkable outside the environment of computer mechanics. Specific engineering problems are being solved by using numerical methods implemented on computers. One of the main advantages of the computer designing is short time and inexpensive simulation of behavior of the model of a real object observed.

At an early stage of design, these programs provide an opportunity to obtain reliable information about the validity of the assumed size and accuracy of the provided constructive solutions. The advantage of using these packages in the design is primarily reflected in the ease of making model and its correction.

Most software packages that have the ability of structural analysis are based on the Finite Element Method - FEM (Finite Element Analysis - FEA). The basic idea of this method is division of the structure into the finite number of small elements that constitute the basis for all considerations [8].

\section{Analysis of the flat honeycomb sandwich panels under uniform load using the ALGOR software package}

In this case, the subject of the analysis is a flat honeycomb sandwich plate under the uniform load, whose dimensions and margins of safety for provided constructive solutions are previously analyzed analytically.

It was found that the honeycomb sandwich panel with the faces of titanium, Ti-6Al-4V, the thickness of 0.035 in $(0.889$ $\mathrm{mm}$ ) and aluminum honeycomb infill 6.5-3/8-50 (5052), the thickness of 1.5 in $(38.1 \mathrm{~mm})$ will withstand the design load of $65 \mathrm{psi}\left(0.448159 \mathrm{~N} / \mathrm{mm}^{2}\right)$.

Fig.13 shows the model of the flat honeycomb sandwich panel with a realistic uniform load. Considering that sandwich plate and load are axially symmetric, we can model and analyze one quarter of the plate.

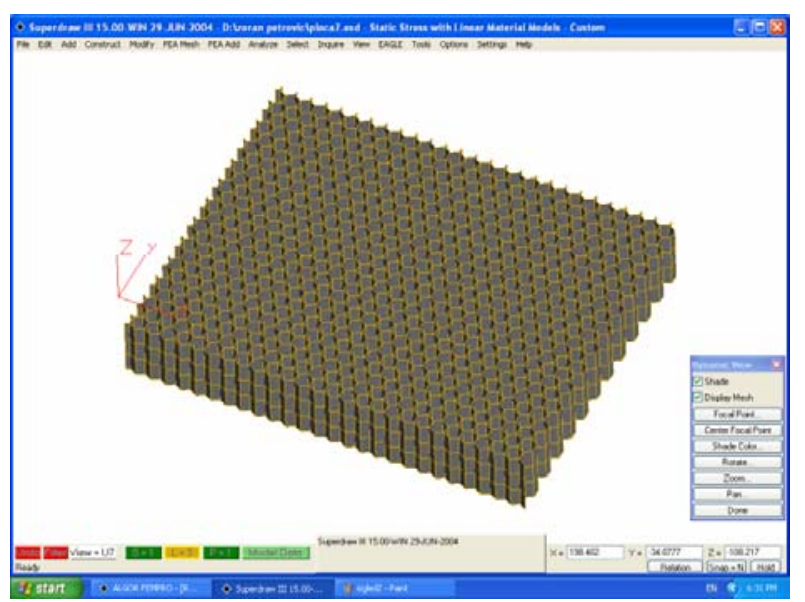

Figure 12. Honeycomb core model

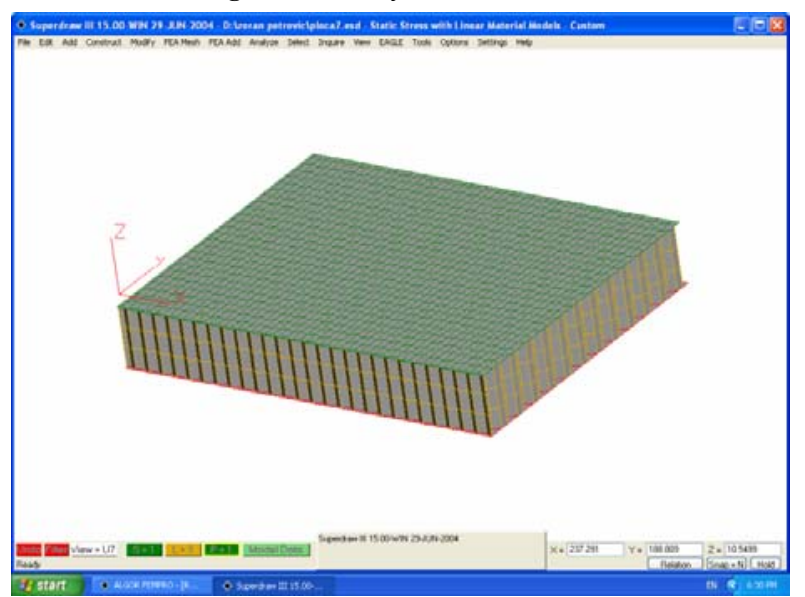

Figure 13. The final model of the honeycomb sandwich panel 


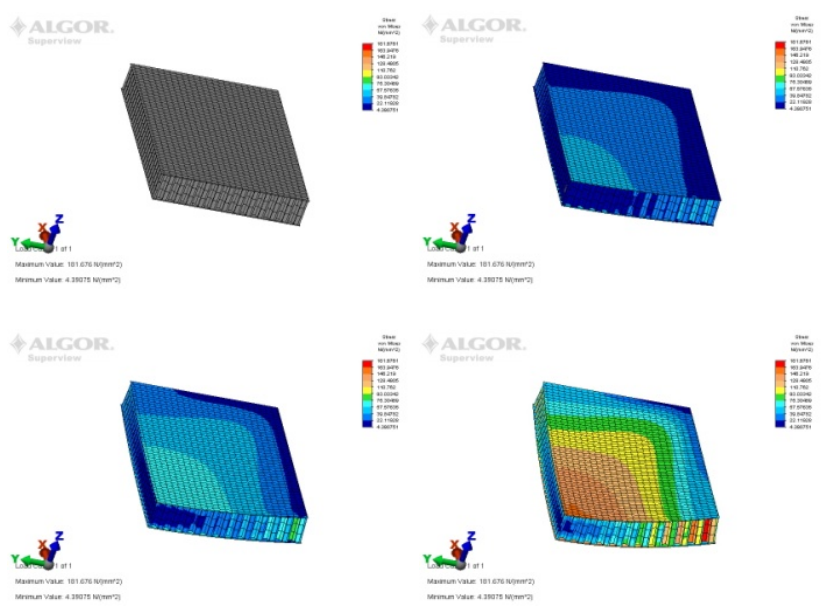

Figure 14. The resulting stresses at $\mathrm{t}=\mathrm{t}_{0}, \mathrm{t}=\mathrm{t}_{1}, \mathrm{t}=\mathrm{t}_{2} \mathrm{i} \mathrm{t}=\mathrm{t}_{4}$ (final).

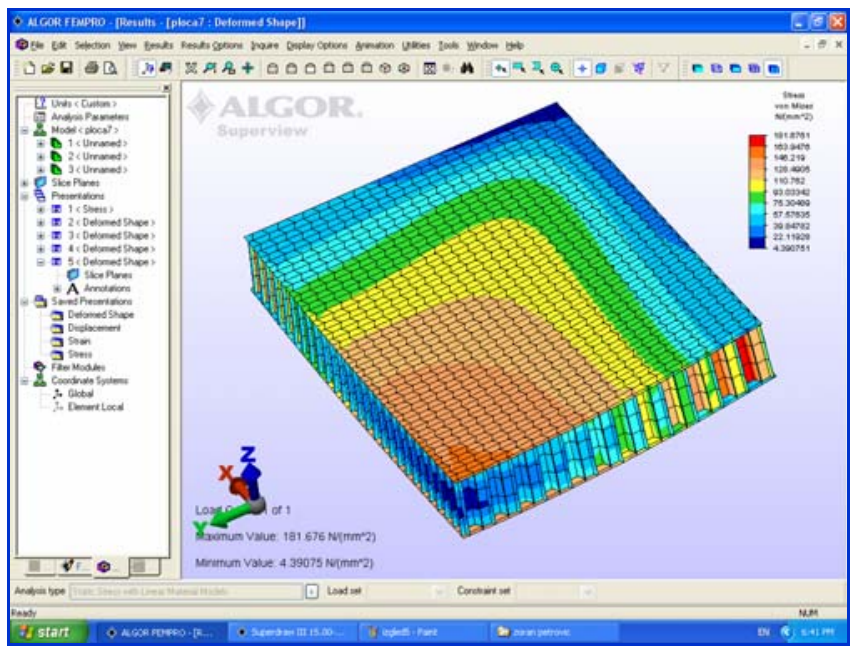

Figure 15. Stress state of the panel (view from above).

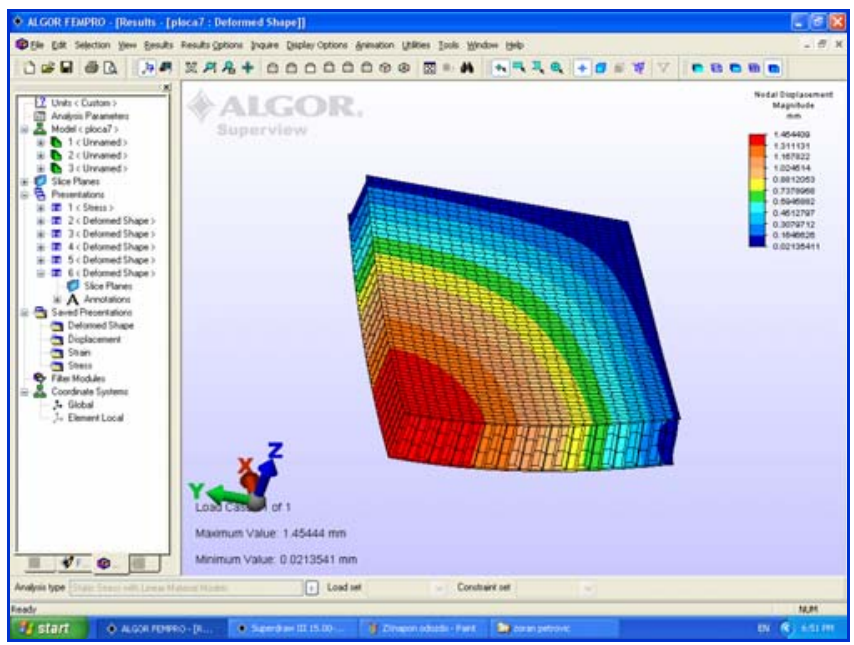

Figure 16. The resulting deflections of the honeycomb sandwich panel under uniform load.

By using the ALGOR software package, following results were obtained, $f=150,57 \mathrm{~N} / \mathrm{mm}^{2}$ and $\delta=-1,454 \mathrm{~mm}$ (Fig. 17).

Comparing the results obtained through analytical and computer procedures, one can conclude their good agreement. Differences for most of the results are from $10 \%$ to $15 \%$, which is quite satisfactory, taking into account that the analytical models are formed on the basis of a number of assumptions and approximations.

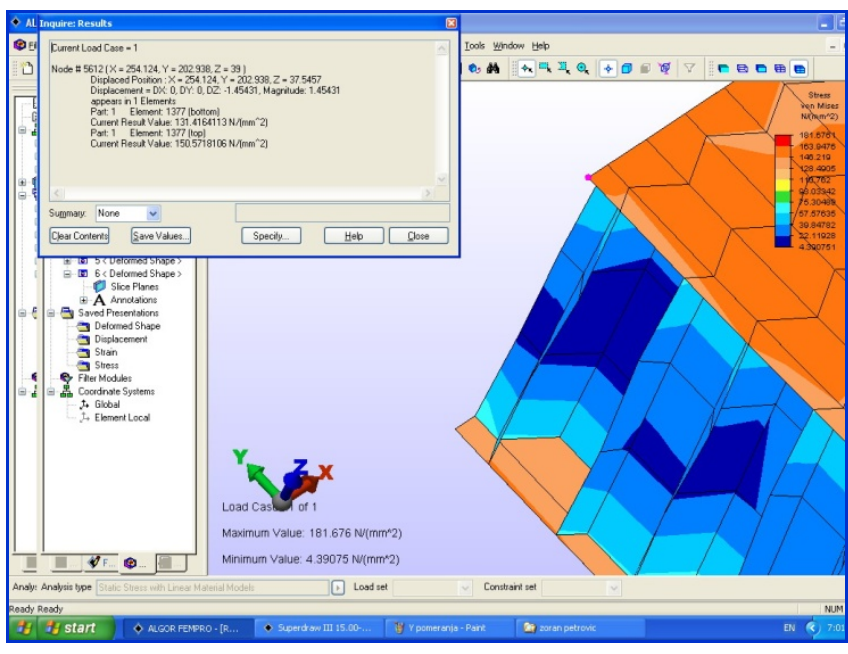

Figure 17. Local values of stress and deflection in the center panel on the upper face

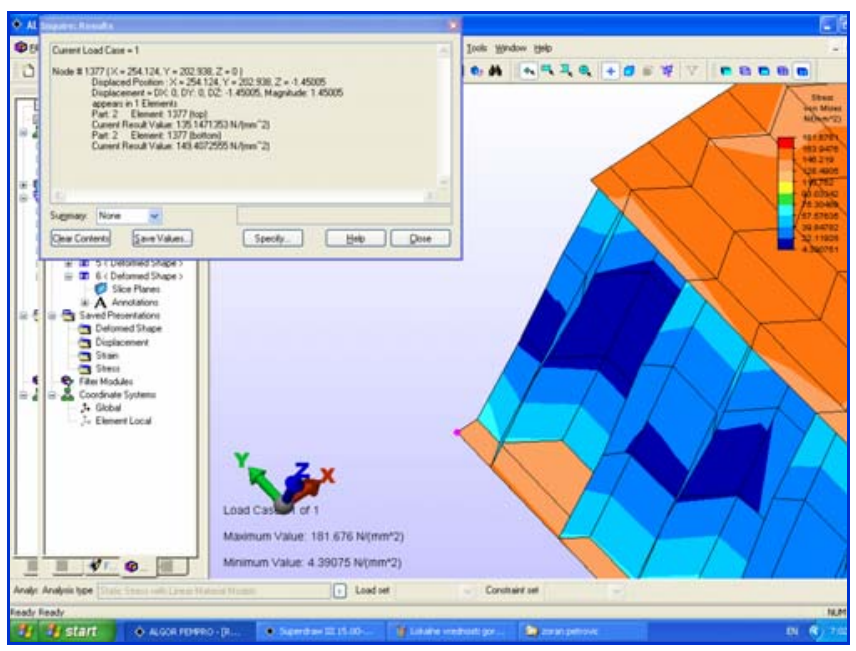

Figure 18. Local values of stress and deflection in the center panel on the lower face

\section{Conclusion}

Structural sandwich is a unique form of the composite structure, and it finds a widespread use in the aerospace industry, where weight saving is a primary concern. Most commercial airliners and helicopters, and nearly all military air and space vehicles, make the extensive usage of the sandwich construction.

The major difference between the analysis procedures for sandwich construction and those for homogeneous structural elements is the inclusion of core shear effects on deflection, buckling and stress.

The design procedure given in this article is intended to guide the designer in sizing the sandwich parts for primary loading properly. These procedures are usually iterative, and optimum design may require the design of several face-core combinations

Comparing the results obtained through analytical and computer procedures, one can conclude their good agreement. Differences for most of the results are from $10 \%$ to $15 \%$, which is quite satisfactory, taking into account that the analytical models are formed on the basis of a number of assumptions and approximations. 


\section{References}

[1] BRUHN,E.F.: Analysis and Design of Flight Vehicle Structures, Tristate Ofset Company, USA, 1973

[2] LUBIN,G.: Handbook of composites, Springer Science \& Business Media, 2013

[3] HEXCEL: Civil Aircraft, http://www.hexcel.com/Markets/Aerospace/Civil.htm

[4] BOEING: Boeing Design Manual, BDM-6700, Introduction to Sandwich Structures, Rev. Org. April 1989

[5] BOEING: Boeing Design Manual, BDM-6710, Flat Honeycomb
Sandwich Structures with Isotropic Faces, Rev. A, May 2000

[6] BOEING: Boeing Design Manual, BDM-4233, 5052 Aluminum honeycomb core, Rev. Org. 01 dec 1989

[7] BOEING: Boeing Design Manual, BDM-4143, Ti-6Al-4V, Rev. B 01 $\operatorname{dec} 1984$

[8] JOVANOVIĆ,M., FILIPOVIĆ,Z.: Primena softverskog paketa Catia u predviđanju mogućih oštećenja realnih vazduhoplovnih konstrukcija, VOC Beograd

\title{
Projektovanje i analiza ravnih saćastih sendvič struktura
}

Strukturalni sendvič kao jedinstvena forma kompozitne strukture je rasprostranjen u vazduhoplovno-kosmičkoj industriji, gde je smanjenje težine primarni interes. Osnovna razlika između postupaka analize za sendvič konstrukciju i onih za homogene strukturalne elemente je uključenje uticaja smicanja jezgra na ugibanje, izvijanje i naprezanje. Postupak analize, koji sledi, prvenstveno je namenjen za vođenje projektanta u pravilnom dimenzionisanju sendvič delova za primarno opterećenje. Ovakvi postupci su obično iterativni i optimalni projekat može zahtevati projektovanje nekoliko kombinacija oplata-jezgro. Poređenjem rezultata dobijenih analitičkim i računarskim putem, može se konstatovati njihovo dobro poklapanje. Razlike za većinu rezultata se kreću od $10 \%$ do $15 \%$ što je sasvim zadovoljavajuće, kada se ima u vidu da su navedeni analitički modeli formirani na bazi niza pretpostavki i aproksimacija.

Ključne reći: sendvič elementi, saćasta struktura, primena u vazduhoplovstvu, letelica, struktura letelice, oplata, strukturna analiza, metoda konačnih elemenata.

\section{Проектирование и анализ плоских сотовых сэндвич - структур}

Сэндвич-структура как уникальная форма композитной структуры распространена в авиационно-космической промышленности, где снижение веса является основным интересом. Основной разницей между методами анализа для сэндвич-конструкции и для однородных структурных элементов является включение воздействия отклонения ядра на прогиб, изгиб и напряжение. Процесс анализа, который следует, в первую очередь предназначен для направления дизайнера в правильном определении размеров сэндвич-компонентов для первичной нагрузки. Эти процедуры, как правило, итеративные и оптимальный проект может потребовать проектирование и сочетание нескольких комбинаций обшивка-ядро. Сравнивая результаты, полученные аналитическими и вычислительными способами, можно сделать вывод, что они хорошо согласуются. Разницы в отношении большинства результатов могут колебаться от $10 \%$ до 15\%, что является вполне удовлетворительным, имея в виду, что приведённые аналитические модели формируются на основе ряда предположений и приближений.

Ключевые слова: сэндвич-элементы, сотовая структура, использование в авиации, самолёт, конструкция самолёта, обшивка, структурный анализ, метод конечных элементов.

\section{Conception et analyse des structures sandwich plates alvéolées}

\begin{abstract}
Le sandwich structural comme une forme unique de structure composite est répandu dans l'industrie aérospatiale où la diminution du poids représente l'intérêt primordial. La différence principale entre le procédé d'analyse pour les construction sandwich et celles pour les éléments structuraux homogènes est l'inclusion de l'influence de déflection du noyau quant au fléchissement , torsion et tension. Le procédé d'analyse qui suit est destiné avant tout pour guider le dessinateur dans la conception adéquate du dimensionnement des parties sandwich pour la charge primaire. Ces procédés sont généralement itératifs et la conception optimale peut exiger plusieurs combinaisons revêtement - noyau. En faisant la comparaison entre les résultats obtenus par la voie analytique et numérique on peut constater bon accord entre eux. Les différences pour la plupart des résultats sont de $10 \%$ à $15 \%$ ce qui est satisfaisant si l'on tient compte du fait que les modèles analytiques cités sont formés à la base d'une série d'hypothèses ou d'approximations.
\end{abstract}

